\title{
NO EFFECT OF A GLYPHOSATE-BASED HERBICIDE ON LARVAL DRAGONFLIES (AESHNA CYANEA) AND ADULT NEWTS (LISSOTRITON VULGARIS) IN A LABORATORY-BASED EXPERIMENT*
}

\author{
János Ujszegi ${ }^{1,2}$, Zoltán GáL ${ }^{1,3}, Z_{\text {sanett Mikó }}{ }^{1}$ and Attila Hettyey ${ }^{1}$ \\ ${ }^{1}$ Lendület Evolutionary Ecology Research Group, Plant Protection Institute, Centre for \\ Agricultural Research, Hungarian Academy of Sciences, Budapest, Hungary \\ E-mails: ujszegi.janos@agrar.mta.hu,miko.zsanett@agrar.mta.hu, hettyey.attila@agrar.mta.hu \\ ${ }^{2}$ Department of Systematic Zoology and Ecology, Eötvös Loránd University, Budapest, Hungary \\ ${ }^{3}$ NARIC, Agricultural Biotechnology Institute, Gödöllö, Hungary \\ E-mail: zoltan.gal89@gmail.com
}

Pesticides can exert negative effects on aquatic organisms at very low concentrations. While several prey taxa are frequently used as models in ecotoxicology studies, there is little information about the pesticide-sensitivity of predators. We examined the effects of a frequently applied glyphosate-based herbicide on two common aquatic predators: larval Aeshna cyanea dragonflies and adult male Lissotriton vulgaris newts, which are top predators in ephemeral water bodies lacking fishes. We exposed predators to the herbicide for 18 days under laboratory conditions and measured potential effects on survival, activity, body mass and predatory activity. To maximize detectability of effects, we applied the herbicide at a concentration of $6.5 \mathrm{mg}$ a. e. glyphosate/L, corresponding to the highest concentration expected in nature. Our results showed that the tested herbicide formulation did not have severe effects on any of the measured fitness-related traits. Results of the present study support the hypothesis that the tested species are insensitive to the herbicide and are able to fulfil their important ecological role of top-down regulation even in highly contaminated habitats. However, potential long-term or indirect effects of the herbicide on the fitness of aquatic predators remain unknown.

Key words: aquatic toxicology, aquatic community, aquatic predators, acute toxicity.

\section{INTRODUCTION}

Pesticides can have detrimental effects on non-target organisms and entire communities (Relyea et al. 2005, Relyea \& Diecks 2008, Peters et al. 2013). Aquatic species are especially sensitive to pesticides, and already low concentrations can lead to mortalities and local extinctions (PÉrez et al. 2011). However, sublethal concentrations are usually found in nature (e.g. STRUGER et al. 2008, Peruzzo et al. 2008, Battaglin et al. 2009). These can also have serious consequences, such as developmental malformations (Lajmanovich et al. 2003),

\footnotetext{
* This article is dedicated to Prof. László Papp, in honor of his 70th birthday and his monumental contribution to the fields of dipteran taxonomy and ecology.
} 
teratogenic effects (PAganelli et al. 2010), physiological and behavioural alterations (BRIDGEs 1999, LAJMANOvich et al. 2011), while exposure to pesticides may also escalate the impact of other biotic and abiotic stressors (RELYeA \& Mills 2001, Sin et al. 2004).

Glyphosate-based herbicides are among the most frequently applied pesticides worldwide (PÉrez et al. 2011, MörTl et al. 2013). Expected worstcase concentrations of these herbicides in shallow water bodies range from 1.4 to $7.6 \mathrm{mg}$ acid equivalent (a.e.) / L (MANn \& Bidwell 1999, Relyea 2012, WAGNER et al. 2013), which is around or higher than the $\mathrm{LC}_{50}$ levels for most North-American and Australian amphibian larvae (Mann \& Bidwell 1999, Relyea \& Jones 2009, Relyea 2012). In Hungary more than 280 tons of glyphosate (only active ingredient) were sold in 2010 (MöRTL et al. 2013), so that severe contamination of aquatic habitats is likely to occur frequently in this part of the world, as well.

Temporary water bodies represent local biodiversity hotspots that harbour many rare and endangered species (Williams et al. 2003, Scheffer et al. 2006). As fishes are usually absent, spiders, larval dragonflies, heteropterans, water-beetles and caudate amphibians are the most important aquatic predators. These generalist predators regulate a wide variety of prey species spanning from zooplankton to amphibian larvae, thereby contributing to the maintenance of the ecological balance in these aquatic communities (TERBORgh et al. 2001, Schmitz et al. 2004, Relyea 2005a). As ephemeral aquatic habitats are relatively small and shallow, and they are often immediately adjacent to cultivated fields, glyphosate concentrations can reach higher levels than measured or predicted for big water bodies with no-spray buffer zones (MANN \& BIDwell 1999, Battaglin et al. 2009, Relyea 2012, Wagner et al. 2013).

Only a few studies have dealt with potential consequences of glyphosatebased herbicides on predatory species of temporary aquatic communities. Sensitivity of predatory arthropods has mainly been tested towards heavy metallic ions and insecticides (Tollett et al. 2009, Relyea \& Edwards 2010), and also very little is known about the sensitivity of adult caudate amphibians towards any pesticide (WAGNer et al. 2013). In the sole previous experimental study that investigated effects of exposure to a glyphosate-based herbicide on larval Aeshna cyanea dragonflies and adult male Lissotriton vulgaris newts we did not find any effects (Ujszegr et al. 2015). However, in that experiment the initially high glyphosate concentration diminished to half of the starting concentration by the end of the experimental period, presumably due to degradation, precipitation and adsorption (KATAgi 2006). Also, Ujszegr et al. (2015) was performed in outdoor mesocosms, and the choice of experimental venue can strongly influence the outcome of ecotoxicological studies (Мıкó et al. 2015). Consequently, further investigations are necessary to ascertain the 
insensitivity of predators inhabiting temporary wetlands to glyphosate-based herbicides.

In this study, we examined the effects of exposure to a permanently high concentration of a glyphosate-based herbicide on dragonfly larvae and adult newts under laboratory conditions. We applied Glyphogan ${ }^{\circledR}$ Classic (Monsanto ME, Brussels, Belgium) at a concentration of $6.5 \mathrm{mg}$ a.e. glyphosate/L. We selected this concentration to be close to the maximum expected worstcase value predicted for shallow water bodies (MANN \& Bidwell 1999, RelyeA 2012, WAGNER et al. 2013), thereby maximizing the detectability of potential impacts. As model species we used two common predators of central European temporary wetlands: larvae of the southern hawker (Aeshna cyanea), an invertebrate sit and wait predator, and adults of the smooth newt (Lissotriton vulgaris), a vertebrate active forager. We assessed if the herbicide affected survival, changes in body mass, activity and predatory activity of animals.

\section{MATERIAL AND METHODS}

We collected 32 larvae of $A$. cyanea (mainly F-2 instars) and 32 adult males of L. vulgaris from four forest ponds in the Pilis Mountains, Hungary on 22 March 2014. (A. cyanea larvae: all originated from $47^{\circ} 44^{\prime} 21^{\prime \prime} \mathrm{N}, 19^{\circ} 0^{\prime} 42^{\prime \prime} \mathrm{E}$; L. vulgaris males: 11 individuals originated from $47^{\circ} 42^{\prime} 27^{\prime \prime} \mathrm{N}, 19^{\circ} 2^{\prime} 24^{\prime \prime} \mathrm{E}, 17$ individuals from $47^{\circ} 42^{\prime} 47^{\prime \prime} \mathrm{N}, 19^{\circ} 2^{\prime} 25^{\prime \prime} \mathrm{E}$ and 4 individuals from $47^{\circ} 42^{\prime} 40^{\prime \prime} \mathrm{N}, 19^{\circ} 2^{\prime} 44^{\prime \prime} \mathrm{E}$ ). We captured dragonfly larvae using dip-nets and newts using plastic funnel traps, and transported animals to the laboratory at the Experimental Station Júliannamajor (Plant Protection Institute, Centre for Agricultural Research, Hungarian Academy of Sciences). We kept dragonfly larvae individually in plastic cups containing 300 mL reconstituted soft water (RSW; APHA, 1985) and a wooden perching site. Newts were placed in groups of four individuals into plastic boxes $(23 \times 19 \times 12 \mathrm{~cm})$ containing $1.5 \mathrm{~L}$ RSW. We kept predators at $19^{\circ} \mathrm{C}$ and a $12: 12 \mathrm{~h}$ light : dark cycle and fed them ad libitum with tubicid worms (Tubifex sp.) until the start of the experiment two days later.

On 16th March we collected 200 eggs from each of 10 clutches of the agile frog (Rana dalmatina) from a pond near Pilisjászfalu, Hungary. We kept eggs separated by family in $10 \mathrm{~L}$ buckets filled with $5 \mathrm{~L} \mathrm{RSW}$, at $19^{\circ} \mathrm{C}$ and a $12: 12 \mathrm{~h}$ light : dark cycle, and hatching tadpoles in large plastic boxes $(37 \times 27 \times 15.5 \mathrm{~cm})$ filled with $10 \mathrm{~L} \mathrm{RSW}$, at $15^{\circ} \mathrm{C}$ and a 12 : $12 \mathrm{~h}$ light: dark cycle. We maintained tadpoles at low temperatures and at high densities to slow their growth. We fed tadpoles with slightly boiled spinach and changed water twice a week. Tadpoles raised this way were, thus, not exposed to either predator cues or the herbicide before their use as food for predators and for testing predatory activity. We used these tadpoles for feeding predators during the experiment and for testing predatory activity.

On 24th March we started the experiment by weighing predators (to the nearest $\mathrm{mg}$ ) and randomly assigned them to herbicide or control treatments, placing them into transparent plastic boxes $(23 \times 19 \times 12 \mathrm{~cm})$, arranged in randomized spatial blocks on a laboratory shelf system. Boxes contained a small plastic pot and a wooden stick as hiding and perching sites. At the start, and subsequent water changes we applied the herbicide by adding $1.19 \mathrm{ml}$ pure Glyphogan ${ }^{\circledR}$ Classic (360 g a.e. glyphosate/L) to $66 \mathrm{~L} \mathrm{RSW}$ which resulted in $6.5 \mathrm{mg}$ a.e. glyphosate/L final concentration. We dispensed $2 \mathrm{~L}$ of this solution into boxes 
assigned to the herbicide treatment. Boxes assigned to the control treatment received $2 \mathrm{~L}$ of RSW. We replicated predator $\times$ treatment combinations 16 times, resulting in a total of 64 experimental units. The average temperature was $17.6^{\circ} \mathrm{C}$ in the laboratory (min.-max.: 16.5-18.6 ${ }^{\circ} \mathrm{C}$; as measured using Onset $\mathrm{HOBO}$ automatic temperature loggers). We applied a $12: 12 \mathrm{~h}$ light : dark cycle during the experiment. Predators were fed every other day with a mixture of two naïve $R$. dalmatina tadpoles (totalling $230 \mathrm{mg}$ ) and $150 \mathrm{mg}$ Tubifex sp. worms. We changed water twice a week, where we used separate nets for each treatment and species to avoid contamination with the herbicide and transmission of species-specific chemical cues.

Sixteen days after start, we observed activity of predators hourly between 10:00 and 18:00. We scored animals active if any part of the body was moving and inactive if it was sitting completely still.

To test the effects of chronic and acute exposure to the herbicide on predatory activity, nineteen days after start we captured predators, weighed them, and randomly assigned them to one of two treatment groups: they were either placed into boxes holding RSW or RSW containing the herbicide (Table 1). Experimental boxes used in this test were similar to those used in the first part of the experiment. Body mass of predators did not differ significantly between the four treatment groups (ANOVA; $A$. cyanea: $F_{3,28}=0.92, P=$ 0.45 ; L. vulgaris: $F_{3,26}=1.237, P=0.32$; Tables $1 \& 2$ ). After one day of acclimation, we tested the predatory activity of animals with small naïve $R$. dalmatina tadpoles ( $100 \mathrm{mg}$ each). We placed 10 tadpoles into each boxes containing a dragonfly larva and 5 tadpoles into each box containing a newt. Four hours later, we counted surviving tadpoles and terminated the experiment. We tested predatory activity both in clear water, and in water containing the herbicide to be able to investigate the effects of chronic and acute exposure on the predators' foraging activity. One newt in the control treatment left the water before the predator activity test, so we excluded this individual from the analyses on behaviour. One larval dragonfly was also excluded due to ecdysis. After the experiment, predators and remaining tadpoles were released at the sites of their collection.

Table 1. Design of the experiment with sample sizes in each group. Note: one newt accidentally died, and another one was excluded, hence the lower numbers in the tests of predatory activity in the case of "L. vulgaris + clear water" treatment group. Also one larval dragonfly was excluded because of ecdysis in the case of "A. cyanea + clear water" treatment group.

\begin{tabular}{lcc}
\hline $\begin{array}{l}\text { Maintenance } \\
\text { (chronic exposure) }\end{array}$ & $\begin{array}{c}\text { Test of predatory acitivity } \\
\text { (acute exposure) }\end{array}$ & No. specimens \\
\hline Aeshna cyanea + clear water & $\begin{array}{c}\text { clear water } \\
\text { herbicide }\end{array}$ & 7 \\
\hline \multirow{2}{*}{ Aeshna cyanea + herbicide } & clear water & 8 \\
\hline \multirow{2}{*}{ Lissotriton vulgaris + clear water } & herbicide & 8 \\
\hline \multirow{2}{*}{ Lissotriton vulgaris + herbicide } & clear water & 8 \\
\hline Duration: 18 days & herbicide & 7 \\
\hline
\end{tabular}


Table 2. Average weights of predators with associated standard deviations in each treatment groups. The four treatments are: 1 . no chronic herbicide exposure \& no acute exposure, 2. no chronic exposure \& acute exposure, 3. chronic exposure \& no acute exposure, 4. chronic exposure \& acute exposure.

\begin{tabular}{lccc}
\hline Species & Treatment group & Average weight $(\mathrm{g})$ & Standard deviation \\
\hline \multirow{3}{*}{ Aeshna cyanea } & 1 & 0.60 & 0.12 \\
& 2 & 0.59 & 0.12 \\
& 3 & 0.63 & 0.15 \\
Lissotriton vulgaris & 4 & 0.70 & 0.20 \\
& 1 & 1.24 & 0.17 \\
& 2 & 1.08 & 0.23 \\
& 3 & 1.26 & 0.24 \\
& 4 & 1.10 & 0.27 \\
\hline
\end{tabular}

\section{Statistical analyses}

We analyzed data on the two species separately. We analyzed body mass data using linear mixed modelling procedures (LMM). To analyse activity, we first calculated mean values for the eight observations, and thereafter used general linear models (GLM). Results of the predatory activity tests were also analysed using GLM in the case of newts, whereas predatory activity of dragonfly larvae was analysed using generalized linear models (GZLM) with quasibinomial error distribution and a logit link function. GLM and GZLM models contained body mass of animals as a covariate. We checked for the homogeneity of variances of response variables using Levene-tests, and investigated the normal distribution of model residuals using diagnostic plots. We included all two-way interactions into initial models and applied backward stepwise removal (Grafen \& HaILs 2002) to avoid potential problems due to the inclusion of non-significant terms (ENGQvist 2005). We obtained statistics for removed variables by re-entering them one by one to the final model. All tests were two-tailed. Statistics were calculated using SPSS Statistics 17.0 for Windows and $\mathrm{R}$ (version 3.2.2) for Windows.

\section{RESULTS}

All predators survived until the end of the experiment except for one newt in the control treatment, which entangled in the plastic shelter and died.

Presence of the herbicide had no influence on body mass change in either predator species (LMM; A. cyanea: $F_{1,49.9}=1.54, P=0.22 ;$ L. vulgaris: $F_{1,57.0}=$ $0.15, P=0.67$; Fig. 1). Independently from exposure to the herbicide, dragonfly larvae nearly doubled their body mass during the 18 days of the experiment $\left(F_{1,50.3}=83.88 ; P<0.001\right)$, while body mass of newts slightly decreased by $c c a$ $8.6 \%$ by the end of the experiment $\left(F_{1,57.9}=5.67 ; P=0.021\right)$. The interaction between the effect of time and exposure was non-significant (for both species $P>$ $0.39)$. 


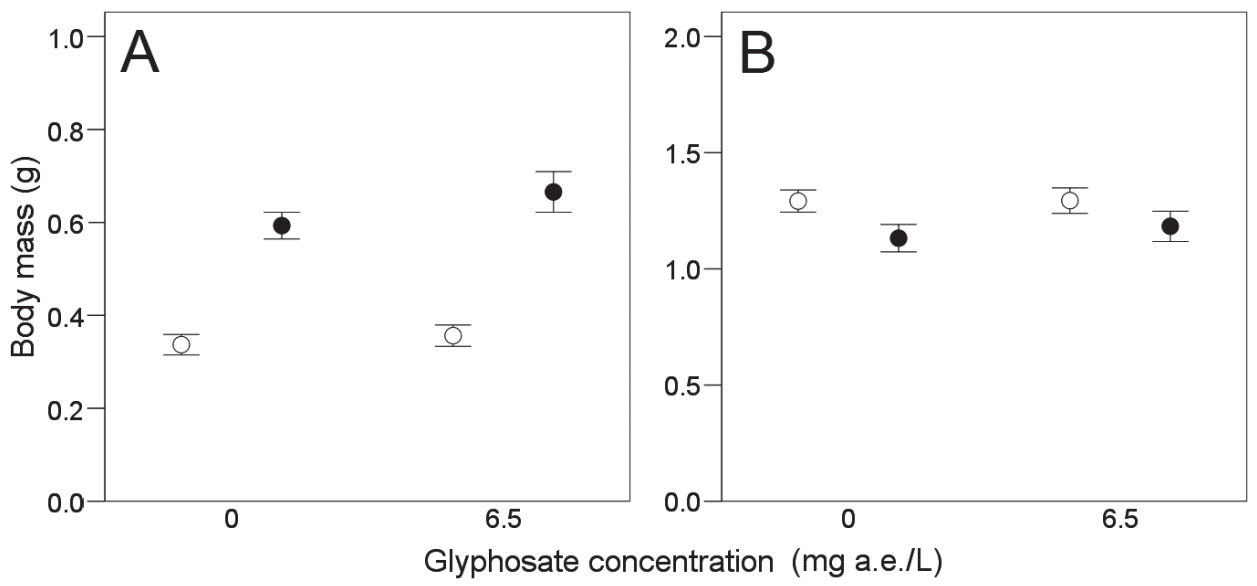

Fig. 1. Body mass (mean $\pm 1 \mathrm{SE}$ ) of A. cyanea larvae (A) and L. vulgaris males $(\mathbf{B})$ before $(\mathrm{O})$ and $\operatorname{after}(\bullet)$ chronic exposure to 0 or $6.5 \mathrm{mg}$ a.e. glyphosate /L for 18 days.

The main effect of the herbicide on the activity of $A$. cyanea larvae was marginally non-significant (GLM; $F_{1,28}=3.79, P=0.06$; Fig. 2 ), and body mass alone did not have an effect on activity either $\left(F_{1,28}=1.78, P=0.19\right)$, however, the interaction between herbicide exposure and body mass was significant $\left(F_{1,28}=4.46, P=0.04\right)$ : smaller individuals moved 5.7 times more in the control treatment than larger ones, but in the herbicide treatment this difference
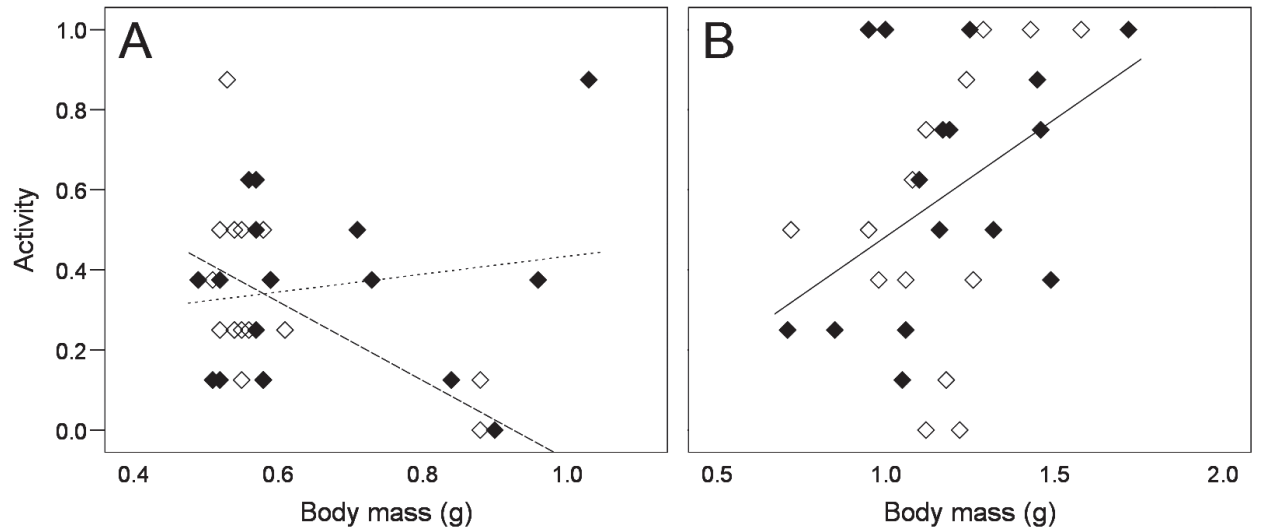

Fig. 2. Activity of A. cyanea larvae (A) and L. vulgaris males (B) on the 16 th day of the experiment $(\diamond=$ control, $\checkmark=$ herbicide treatment). Activity corresponds to the proportion of the times when animals were observed active. Note that heavier dragonfly larvae were less active, than lighter ones in the control treatment (dashed line), but this relationship disappeared in the herbicide treatment (dotted line). Activity of heavier newts was always higher, than that of lighter ones, independently from exposure to the herbicide (solid line). 
disappeared. Activity of newts was unaffected by exposure to the herbicide $\left(F_{1,27}=0.45, P=0.51\right.$; Fig. 2$)$, but body mass had a significant effect: heavier individuals were 1.35-fold more active than lighter ones $\left(F_{1,28}=5.94, P=0.021\right)$. The interaction between exposure and body mass was non-significant in the case of newts $\left(F_{1,26}=0.24, P=0.63\right)$.

In the test on predatory activity, the number of consumed tadpoles was not significantly affected by either chronic or acute exposure to the herbicide (A. cyanea: GZLM; chronic exposure: $t=-0.58, P=0.57$, acute exposure: $t=$ $0.01, P=0.99$; L. vulgaris: GLM; chronic exposure: $F_{1,27}=0.02, P=0.88$, acute exposure: $F_{1,27}=1.60, P=0.22$; Fig. 3 ). The number of consumed tadpoles was affected by body mass in the case of newts $\left(\mathrm{GLM} ; F_{1,28}=12.68, P=0.001\right)$ independently from the treatments. Body mass had no effect on the predatory activity of dragonfly larvae (GZLM; $t=0.22, P=0.83)$, and none of the two-way interactions were significant (all $P>0.40$ ).

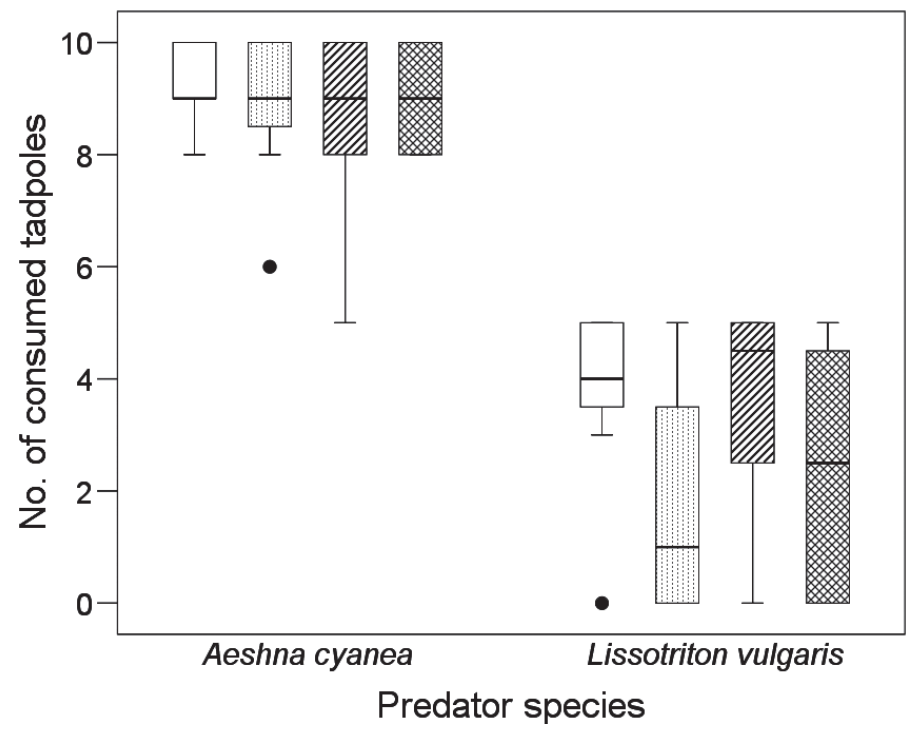

Fig. 3. Numbers of consumed tadpoles in the case of A. cyanea larvae and adult L. vulgaris males in the four treatments of the experiment on predation activity. Explanation of shading types representing the four treatments: 1 (white): no chronic herbicide exposure \& no acute exposure, 2 (dotted): no chronic exposure \& acute exposure, 3 (striated): chronic exposure \& no acute exposure, 4 (reticulated): chronic exposure \& acute exposure (Vertical lines depict medians, boxes represent interquartiles, bars represent ranges, dots indicate outliers). Predatory activity was not affected by exposure to the herbicide in either predator. The apparent treatment effect in newts was caused by size dependent predatory foraging activity. 


\section{DISCUSSION}

Our laboratory experiment indicated that chronic exposure to relatively high concentrations (6.5 mg a.e. / L) of the herbicide formulation Glyphogan ${ }^{\circledR}$ Classic do not have severe impacts either on $A$. cyanea larvae or on adult $L$. vulgaris males. These results corroborate previous findings delivered by an outdoor mesocosm experiment about the insensitivity of these predator species to glyphosate-based herbicides (Ujszegr et al. 2015). This confirmation of earlier results was vital, because the outcome of ecotoxicological experiments can greatly depend on the experimental venue (Mikó et al. 2015).

The few existing reports on the effects of herbicides, insecticides and heavy metallic ions on survival of larval odonate predators came to a similar conclusion as our study, suggesting that dragonfly larvae are highly tolerant not only to glyphosate-based herbicides, but also to several other forms of anthropogenic contaminants (Rohr \& Cumrine 2005, Relyea 2005a, Tollett et al. 2009, Ujszegr et al. 2015). During the 18 days of the present experiment, all dragonfly larvae survived and nearly doubled their body mass independently of exposure to the herbicide, suggesting low (if any) metabolic costs of detoxification (Fig. 1). Only activity was slightly affected by the interaction between herbicide exposure and body mass, where heavier individuals were less active compared to lighter ones, but only in the control treatment, and heavy individuals were more active in the herbicide treatment than in the control treatment. JANSSENS and Sтокs (2012) found that activity and related predatorinduced changes in behaviour of larval Enallagma cyathigerum, a zygopteran dragonfly, may be impaired by acute exposure to a glyphosate-based herbicide, but these changes were also relatively slight and did not translate into elevated mortality in the presence of free-ranging predators. It is possible that in our experiment the observed increased activity of large herbicide-exposed dragonfly larvae was a result of attempted escape from waters with high pesticide concentrations, but this hypothesis remains speculative and would need further investigation. The lack of strong effects of herbicide-exposure on A. cyanea behaviour is further strengthened by the observation that predatory activity was also not affected by either acute, or chronic exposure to the herbicide (Fig. 3).

Effects of the herbicide were similarly slight on adult smooth newts as on dragonfly larvae. Although another formulation of a glyphosate-based herbicide has been reported to be lethal already at relatively low concentrations (2-3 $\mathrm{mg}$ a.e. glyphosate/L) to tadpoles, larval newts and salamanders (RelyeA \& JONEs 2009), we did not experience elevated mortality in adult newts even at a higher herbicide concentration. This is in line with previous findings on adult animals (Relyea et al. 2005, WAgNer \& Lötters 2013, Ujszegr et al. 2015). As 
Edginton et al. (2004) suggested, surfactants in glyphosate based herbicides (e.g. polyethoxylated tallow amine; POEA) may impair the functioning of the gills of larval amphibians. At the same time it seems that these chemicals have no significant effect on lung-breathing adults, despite the importance of skinbreathing (FEDER \& BurgGren 1985). Herbicide exposure also did not affect body mass change in adult newts, which is in line with our previous findings as well (Ujszegr et al. 2015). The observed slight reduction in body mass of newts by the end of the chronic exposure time (Fig. 1), which was independent from herbicide-exposure, was most likely caused by the stress due to unnatural laboratory conditions, and perhaps less food available, than in mesocosms, where zooplankton would provide further food supply. We did not experience changes in activity or predation efficiency due to herbicideexposure in newts either. Former studies indicated that pesticides can alter activity and behaviour of anuran larvae, the most frequently used amphibian models in ecotoxicology (Bridges 1999, Moore et al. 2015). At the same time, Relyea and Edwards (2010) did not find any effect of insecticide exposure on predatory activity of adult Notophthalmus viridescens newts, similarly to our findings (Ujszegr et al. 2015, present experiment). Body mass, however, positively affected both activity and predatory activity. This may be due to larger individuals requiring more food, being more able to prey on large prey items, such as tadpoles, and being less vulnerable to other predators than their smaller conspecifics (WILBUR 1988, URban 2007).

This insensitivity of predators to the herbicide in absolute terms and also relative to anuran larvae can have serious negative consequences for tadpoles in contaminated habitats: while the mortality rate of tadpoles is already elevated, their growth, development and overall physiological performance may also be constrained due to contamination (LajManovich et al. 2003, 2011), so that tadpoles may suffer extreme losses from predators that remain unaffected by the herbicide. This effect may be dampened once tadpole densities drop low and generalist predators, like newts and dragonfly larvae switch to other, more resistant prey taxa, such as scuds (Folmar et al. 1979) or zooplankton species (RELYeA 2005a). Also, morphological and behavioural responses of tadpoles to the herbicide closely resemble those induced by predators (RELYEA 2012), and are likely to provide some level of protection against predation. Nonetheless, tadpoles, and several other prey taxa, are likely to suffer additional losses from elevated predation pressure due to the relative insensitivity of predators, which may add up on direct effects of herbicides.

In conclusion, the studied glyphosate-based herbicide did not have an effect on survival, body mass change, and predatory activity of either larval $A$. cyanea dragonflies or adult male $L$. vulgaris individuals, even though the applied concentration was close to the expected worst-case values and exposure 
lasted for 18 days. The only effect we observed was slightly elevated activity in large (but not small) dragonfly larvae, while activity remained unaffected in newts. These results confirmed previous findings of no severe effect of herbicide-exposure on the same species obtained in a mesocosm experiment (UJSzEgr et al. 2015). In addition, here we demonstrated that the herbicide also does not have severe effects on the studied predators if it is present at a constantly high concentration and does not diminish due to degradation, precipitation or adsorption. These results are surprising, because glyphosate-based herbicides have been shown to have strong impacts at lower concentrations on other aquatic arthropods and amphibians even in larval (ReLyeA 2005b, ReLyea \& Jones 2009, Pérez et al. 2011) or adult stages (BrüHl et al. 2011). Hence, our results stress the need for further studies uncovering differences between the sensitivity of different taxa and life stages. Furthermore, revealing longterm effects of exposure and assessing indirect effects via trophic cascades on these top predators will also be necessary for understanding consequences of herbicide-contamination in their entirety.

Acknowledgements - We thank L. Jókai for assistance during the experiment and the Pilisi Parkerdő Zrt. for allowing us to use their roads. The Közép-Duna-Völgyi KTVF issued the permission (KTF: 603-4/2014.), and the Ethical Commission of the MTA ATK NÖVI approved the investigation in accordance with Good Scientific Practice guidelines and national legislation. Our research was supported by the Lendület Programme of the Hungarian Academy of Sciences (MTA, LP2012-24/2012), the FiKut Programme of the Hungarian Academy of Sciences (Mv-59/2013) and an FP7 Marie Curie Career Integration Grant (PCIG13-GA-2013-631722). The authors have no conflicts of interest to declare.

\section{REFERENCES}

APHA (1985) Standard methods for the examination of water and wastewater. 16. ed. American Public Health Association, Washington D.C.,1268 pp.

Battaglin, W. A., Rice, K. C., Focazio, M. J., Salmons, S. \& Barry, R. X. (2009) The occurrence of glyphosate, atrazine, and other pesticides in vernal pools and adjacent streams in Washington, DC, Maryland, Iowa, and Wyoming, 2005-2006. Environmental Monitoring and Assessment 155: 281-307. http://dx.doi.org/10.1007/s10661-008-0435-y

Bridges, C. M. (1999) Effects of a pesticide on tadpole activity and predator avoidance behavior. Journal of Herpetology 33: 303-306. http://dx.doi.org/10.2307/1565728

Brühl, C. A., Pieper, S. \& Weber, B. (2011) Amphibians at risk? Susceptibility of terrestrial amphibian life stages to pesticides. Environmental Toxicology and Chemistry 30: 2465-2472. http://dx.doi.org/10.1002/etc.650

Edginton, A. N., Sheridan, P. M., Stephenson, G. R., Thompson, D. G. \& Boermans, H. J. (2004) Comparative effects of $\mathrm{pH}$ and Vision ${ }^{\circledR}$ herbicide on two life stages of four anuran amphibian species. Environmental Toxicology and Chemistry 23: 815-822. http:// dx.doi.org/10.1897/03-115 
EngQvist, L. (2005) The mistreatment of covariate interaction terms in linear model analyses of behavioural and evolutionary ecology studies. Animal Behaviour 70: 967-971. http://dx.doi.org/10.1016/j.anbehav.2005.01.016

Feder, M. E. \& Burggren, W. W. (1985) Cutaneous gas exchange in vertebrates: design, patterns, control and implications. Biological Reviews of the Cambridge Philosophical Society 60: 1-45. http://dx.doi.org/10.1111/j.1469-185X.1985.tb00416.x

Folmar, L. C., Sanders, H. O. \& Julin, A. M. (1979) Toxicity of the herbicide glyphosate and several of its formulations to fish and aquatic invertebrates. Archives of Environmental Contamination and Toxicology 8: 269-278. http://dx.doi.org/10.1007/BF01056243

Grafen, A. \& Hails, R. (2002) Modern statistics for the life sciences. Oxford University Press, Oxford, $351 \mathrm{pp}$.

JANsSENS, L. \& StoKs, R. (2012) How does a pesticide pulse increase vulnerability to predation? Combined effects on behavioral antipredator traits and escape swimming. Aquatic Toxicology 110-111: 91-98. http://dx.doi.org/10.1016/j.aquatox.2011.12.019

Katagi, T. (2006) Behavior of pesticides in water-sediment systems. Reviews of Environmental Contamination and Toxicology 187: 133-251. http://dx.doi.org/10.1007/0-387-32885-8_4

Lajmanovich, R. C., Attademo, A. M., Peltzer, P. M., Junges, C. M. \& Cabagna, M. C. (2011) Toxicity of four herbicide formulations with glyphosate on Rhinella arenarum (Anura: Bufonidae) tadpoles: B-esterases and glutathione S-transferase inhibitors. Archives of Environmental Contamination and Toxicology 60: 681-689. http://dx.doi. org/10.1007/s00244-010-9578-2

Lajmanovich, R. C., Sandoval, M. T. \& Peltzer, P. M. (2003) Induction of mortality and malformation in Scinax nasicus tadpoles exposed to glyphosate formulations. Bulletin of Environmental Contamination and Toxicology 70: 612-618. http://dx.doi.org/10.1007/ s00128-003-0029-x

ManN, R. M. \& Bidwell, J. R. (1999) The toxicity of glyphosate and several glyphosate formulations to four species of southwestern Australian frogs. Archives of Environmental Contamination and Toxicology 36: 193-199. http://dx.doi.org/10.1007/s002449900460

Mikó, Z., Ujszegi, J., GÁL, Z., Imrei, Z. \& Hettyey, A. (2015) Choice of experimental venue matters in ecotoxicology studies: Comparison of a laboratory-based and an outdoor mesocosm experiment. Aquatic Toxicology 167: 20-30. http://dx.doi.org/10.1016/j. aquatox.2015.07.014

Moore, H., Chivers, D. P. \& Ferrari, M. C. O. (2015) Sub-lethal effects of Roundup ${ }^{\mathrm{TM}}$ on tadpole anti-predator responses. Ecotoxicology and Environmental Safety 111: 281-285. http://dx.doi.org/10.1016/j.ecoenv.2014.10.014

Mörtl, M., Németh, G., Juracsek, J., Darvas, B., Kamp, L., Rubio, F. \& Székács, A. (2013) Determination of glyphosate residues in Hungarian water samples by immunoassay. Microchemical Journal 107: 143-151. http://dx.doi.org/10.1016/j.microc.2012.05.021

Paganelli, A., Gnazzo, V., Acosta, H., López, S. L. \& Carrasco, A. E. (2010) Glyphosatebased herbicides produce teratogenic effects on vertebrates by impairing retinoic acid signaling. Chemical Research in Toxicology 23: 1586-1595. http://dx.doi.org/10.1021/ tx1001749

Pérez, G. L., Vera, M. S. \& Miranda, L. A. (2011) Effects of herbicide glyphosate and glyphosate-based formulations on aquatic ecosystems. Pp. 343-368. In: Kortekamp, A. (ed.): Herbicides and Environment. InTech, Rijeka. http://dx.doi.org/10.5772/12877

Peruzzo, P. J., Porta, A. A. \& Ronco, A. E. (2008) Levels of glyphosate in surface waters, sediments and soils associated with direct sowing soybean cultivation in north pampasic region of Argentina. Environmental Pollution 156: 61-66. http://dx.doi. org/10.1016/j.envpol.2008.01.015 
Peters, K., Bundschuh, M. \& Schäfer, R. B. (2013) Review on the effects of toxicants on freshwater ecosystem functions. Environmental Pollution 180: 324-329. http://dx.doi. org/10.1016/j.envpol.2013.05.025

RelyeA, R. A. (2005a) The impact of insecticides and herbicides on the biodiversity and productivity of aquatic communities. Ecological Applications 15: 618-627. http://dx.doi. org/10.1890/03-5342

RelyeA, R. A. (2005b) The lethal impacts of Roundup and predatory stress on six species of North American tadpoles. Archives of Environmental Contamination and Toxicology 48: 351-357. http://dx.doi.org/10.1007/s00244-004-0086-0

RelyeA, R. A. (2012) New effects of Roundup on amphibians: predators reduce herbicide mortality; herbicides induce antipredator morphology. Ecological Applications 22: 634-647. http://dx.doi.org/10.1890/11-0189.1

RelyeA, R. A. \& Diecks, N. (2008) An unforeseen chain of events: lethal effects of pesticides on frogs at sublethal concentrations. Ecological Applications 18: 1728-1742. http:// dx.doi.org/10.1890/08-0454.1

Relyea, R. A. \& Edwards, K. (2010) What doesn't kill you makes you sluggish: How sublethal pesticides alter predator-prey interactions. Copeia 2010: 558-567. http://dx.doi. org/10.1643/CE-09-027

Relyea, R. A. \& Jones, D. K. (2009) The toxicity of Roundup Original Max® to 13 species of larval amphibians. Environmental Toxicology and Chemistry 28: 2004-2008. http:// dx.doi.org/10.1897/09-021.1

Relyea, R. A. \& Mills, N. (2001) Predator-induced stress makes the pesticide carbaryl more deadly to gray treefrog tadpoles (Hyla versicolor). Proceedings of the National Academy of Sciences of the United States of America 98: 2491-2496. http://dx.doi.org/10.1073/ pnas.031076198

Relyea, R. A., Schoeppner, N. M. \& Hoverman, J. T. (2005) Pesticides and amphibians: the importance of community context. Ecological Applications 15: 1125-1134. http://dx.doi. org/10.1890/04-0559

Rohr, J. R. \& Cumrine, P. W. (2005) Effects of an herbicide and an insecticide on pond community structure and processes. Ecological Applications 15: 1135-1147. http://dx.doi. org/10.1890/03-5353

Scheffer, M., van Geest, G.J., Zimmer, K., Jeppesen, E., Søndergaard, M., Butler, M. G., Hanson, M. A., Declerck, S. \& De Meester, L. (2006) Small habitat size and isolation can promote species richness: second-order effects on biodiversity in shallow lakes and ponds. Oikos 112: 227-231. http://dx.doi.org/10.1111/j.0030-1299.2006.14145.x

Schmitz, O. J., Krivan, V. \& Ovadia, O. (2004) Trophic cascades: the primacy of trait-mediated indirect interactions: Primacy of trait-mediated indirect interactions. Ecology Letters 7: 153-163. http://dx.doi.org/10.1111/j.1461-0248.2003.00560.x

Sih, A., Bell, A. M. \& Kerby, J. L. (2004) Two stressors are far deadlier than one. Trends in Ecology \& Evolution 19: 274-276. http://dx.doi.org/10.1016/j.tree.2004.02.010

Struger, J., Thompson, D., Staznik, B., Martin, P., McDaniel, T. \& Marvin, C. (2008) Occurrence of Glyphosate in Surface Waters of Southern Ontario. Bulletin of Environmental Contamination and Toxicology 80: 378-384. http://dx.doi.org/10.1007/s00128008-9373-1

Terborgh, J., Lopez, L., Nuñez, P., Rao, M., Shahabuddin, G., Orihuela, G., Riveros, M., Ascanio, R., Adler, G. H., Lambert, T. D. \& Balbas, L. (2001) Ecological meltdown in predator-free forest fragments. Science 294: 1923-1926. http://dx.doi.org/10.1126/ science.1064397 
Tollett, V. D., Benvenutti, E. L., Deer, L. A. \& Rice, T. M. (2009): Differential toxicity to $\mathrm{Cd}, \mathrm{Pb}$, and $\mathrm{Cu}$ in dragonfly larvae (Insecta: Odonata). Archives of Environmental Contamination and Toxicology 56: 77-84. http://dx.doi.org/10.1007/s00244-008-9170-1

Ujszegi, J., GÁl, Z., Miкó, Z. \& Hettyey, A. (2015) No observable effect of a glyphosatebased herbicide on two top predators of temporal water bodies. Environmental Toxicology and Chemistry 34: 307-313. http://dx.doi.org/10.1002/etc.2798

URBAN, M. C. (2007) The growth-predation risk trade-off under a growing gape-limited predation threat. Ecology 88: 2587-2597. http://dx.doi.org/10.1890/06-1946.1

WAGNER, N. \& LöTtERs, S. (2013) Effects of water contamination on site selection by amphibians: experiences from an arena approach with European frogs and newts. Archives of Environmental Contamination and Toxicology 65: 98-104. http://dx.doi.org/10.1007/ s00244-013-9873-9

Wagner, N., Reichenbecher, W., Teichmann, H., Tappeser, B. \& Lötters, S. (2013) Questions concerning the potential impact of glyphosate-based herbicides on amphibians. Environmental Toxicology and Chemistry 32: 1688-1700. http://dx.doi.org/10.1002/ etc. 2268

Wilbur, H. M. (1988) Interactions between growing predators and growing prey. Pp. 157172. In: Ebenman, B. \& Persson, L. (eds): Size-structured populations. Springer, New York. http://dx.doi.org/10.1007/978-3-642-74001-5_11

Williams, P., Whitfield, M., Biggs, J., Bray, S., Fox, G., Nicolet, P. \& Sear, D. (2003) Comparative biodiversity of rivers, streams, ditches and ponds in an agricultural landscape in Southern England. Biological Conservation 115: 329-341. http://dx.doi. org/10.1016/S0006-3207(03)00153-8

Received October 2, 2015, accepted June 13, 2016, published October 6, 2016 


\section{SYNTHESYS D}

\section{Synthesis of systematic resources}
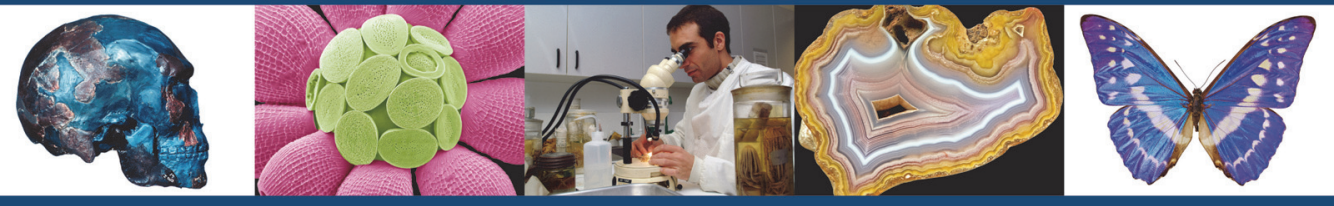

\section{Access to research infrastructures}

SYNTHESYS offers unique research opportunities to scientists from all over Europe. Access is provided to:

- European collections comprising more than half of the world's natural history specimens

- world class libraries

- state-of-the-art facilities including imaging, chemical, and molecular laboratories

- support from in-house scientists, including researchers, facilities staff, and collections managers

Participation is free of charge and is provided on the basis of scientific excellence of a proposal, reviewed by a Selection Panel. Priority is given to new users. A typical project is 1-6 weeks in duration.

The 18 partner institutions offer access via 11 national Taxonomic Access Facilities (TAFs).

AT-TAF: Naturhistorisches Museum, Vienna

BE-TAF: Royal Belgian Institute of Natural Sciences, Brussels; Royal Museum for Central Africa, Tervuren

CZ-TAF: Národní Muzeum, Prague

DE-TAF: Botanischer Garten und Botanisches Museum Berlin-Dahlem, Berlin; Museum für Naturkunde, Berlin; Senckenberg Gesellschaft für Naturforschung, Frankfurt, Dresden, Görlitz and Müncheberg; Staatliches Museum für Naturkunde, Stuttgart
DK-TAF: University of Copenhagen

ES-TAF: Museo Nacional de Ciencias Naturales \& Real Jardín Botánico, Madrid

FR-TAF: Muséum National d'Histoire Naturelle, Paris

GB-TAF: Natural History Museum, London; Royal Botanic Gardens, Kew; Royal Botanic Garden, Edinburgh

HU-TAF: Hungarian Natural History Museum, Budapest

NL-TAF: Naturalis Biodiversity Center, Leiden

SE-TAF: Naturhistoriska riksmuseet, Stockholm

SYNTHESYS will provide finance for:

u research costs

uper diem contribution towards living costs

n international travel and accommodation

nlogistical support at the host institution

Contact SYNTHESYS for details of the online application process and deadlines:

Annual Calls for proposals in October (2013 - 2016)

Visits will be scheduled between January 2014 and August 2017

email: synthesys@nhm.ac.uk

www.synthesys.info

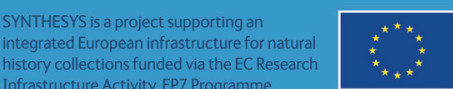

